\title{
Ethnic identity and racial attitudes in a minority group of mixed racial origin
}

Timothy B. Smith

Brigham Young University, tbs@byu.edu

Joy Stratton

Brigham Young University

Christopher R. Stones

Rhodes University

Anthony Naidoo

University of Stellenbosch

Follow this and additional works at: https://scholarsarchive.byu.edu/facpub

Part of the Counseling Psychology Commons

\section{Original Publication Citation}

Smith, T. B., Stratton, J., Stones, C. R., \& Naidoo, A. (2003). Ethnic identity and racial attitudes in a minority group of mixed racial origin. Psychological Reports, 92, 284-290.

\section{BYU ScholarsArchive Citation}

Smith, Timothy B.; Stratton, Joy; Stones, Christopher R.; and Naidoo, Anthony, "Ethnic identity and racial attitudes in a minority group of mixed racial origin" (2003). Faculty Publications. 1994.

https://scholarsarchive.byu.edu/facpub/1994 


\section{Running Head: ETHNIC IDENTITY AND RACISM}

Smith, T. B., Stratton, J., Stones, C. R., \& Naidoo, A. (2003). Ethnic identity and racial attitudes in a minority group of mixed racial origin. Psychological Reports, 92, 284-290.

Ethnic Identity and Racial Attitudes

in a Minority Group of Mixed Racial Origin

Timothy B. Smith

Joy Stratton

Brigham Young University

Christopher R. Stones

Rhodes University

Anthony Naidoo

University of Stellenbosch 
Limited information exists on the racial attitudes and ethnic identities of groups of mixed racial origin. The present research tested the hypotheses that the construct of ethnic identity is valid among such groups and that ethnic identity is related to out-group prejudice, as predicted by social identity theory. The Multigroup Ethnic Identity Measure, the Anti-White Scale, and the Subtle Racism Scale were administered to 70 South Africans of mixed racial decent, the so-called Coloureds. A factor analysis supported the structural validity of the measure of ethnic identity with this sample, but correlations between scales did not support the prediction that group identity would be positively associated with out-group prejudice. Group identity was positively related to positive attitudes toward Whites, supporting the tenets of social dominance theory. 


\section{Ethnic Identity and Racial Attitudes \\ in a Minority Group of Mixed Racial Origin}

Social identity theory (e.g., Tajfel, 1978) and theories of ethnocentrism (e.g., LeVine \& Campbell, 1972) state that racial prejudice increases as groups seek to maintain positive conceptions of themselves through negative comparisons and competition with other groups. Although much research from this theoretical point of view has been done in laboratory settings, the study of groups with a complex history of oppression or subjugation has been less frequent (Bornman \& Appelgryn, 1999). In particular, very little research has been conducted with groups of mixed racial or ethnic origin, whose interaction patterns with other groups tend to be problematic and complex. In a social world where the boundaries of in-group and out-group are notable, members of "mixed" groups must negotiate a place in-between perceived extremes (Root, 1992). They are neither one group nor the other, yet they are both. Thus mixed groups provide a unique context from which to assess social identity theory.

The assumption of social identity theory (e.g., Tajfel, 1978) that a group maintains positive self-conceptions via negative comparisons with other groups is potentially problematic with groups of mixed origin. Prejudice against these groups could produce a conflict with aspects of their own heritage (e.g., Middlebrook, 1996). It is difficult to reject a group that is fundamentally similar to your own. Thus it is uncertain to what degree the assumption of social identity theory holds true for groups whose mixed origin makes prejudice against those groups potentially conflict with their own identity. 
Study of the ethnic identity of racially-mixed groups is particularly needed because these groups face unusual challenges in their identity development (Aikins, 1995; Tizard \& Phoenix, 1995). Because society tends to emphasize differences between the predominant ethnic groups (i.e., Black vs. White), people who share attributes of both groups are often marginalized. The marginal social status of people of mixed ancestry is seen as a primary cause of their difficulties in establishing a unique ethnic identity (Middlebrook, 1996).

Whereas social identity theory emphasizes in-group and out-group dynamics, social dominance theory suggests that the social status of groups (i.e., the extent to which they are perceived as having social and political power, high educational standing and so on) may be an important mediator of the association between ethnic identity and prejudice (Sidanius \& Pratto, 1999). Social dominance theory may therefore offer a compelling rationale as to the relationship of ethnic identity to racial prejudice among groups of mixed origin. Wherever a mixed group is relegated to an inferior or marginal social status, they may identify more with the group of origin that has lower social status and hold prejudicial attitudes toward the group of higher social status. However, the relationship between prejudice and ethnic identity is largely untested among groups of mixed origin.

Typically, researchers have conceived ethnic identity development as linear and categorical in nature, but this conceptualization is challenged by the experiences of people who do not represent a single category (Root, 1992). Ethnic identity may be more complex and dynamic for such groups. What research has been done on the ethnic identity of groups of mixed origin has emphasized unique factors that differ from 
traditional models of ethnic identity development (e.g., Aikins, 1995). For example, in a cross-cultural study of four South African ethnic groups, only the group of mixed racial origin had unexpected correlation patterns between measures of racial attitudes and ethnic identity when compared to Black and White South Africans (Smith \& Stones, 1999). That group, the so-called Coloureds ${ }^{1}$, originated from the mixing of the early Dutch (and later British) settlers with the indigenous African groups in the Cape. During the years of apartheid they were granted more privileges than Blacks but much less privileges than Whites. Because of this social hierarchy and because they represent a small minority of the South African population, so-called Coloureds have been marginalized in South African society (Kinloch, 1985). Even after the dismantling of apartheid and the transition to a democratic government in 1994, the marginalized status of so-called Coloureds has continued because they have neither the political power of the Black South Africans nor the economic power of White South Africans. In the study by Smith and Stones (1999), ethnic identity among the so-called Coloured participants was positively correlated with racial attitude ambivalence and instability, contrary to the expectation that in-group attitudes should be negatively correlated with measures of out-group attitudes, which result was obtained only in the data from the non-mixed Black and White South Africans. These results challenge the assumption of social identity theory and question the validity of the traditional construct of ethnic identity with groups of mixed racial origin.

The present study was therefore designed to test two hypotheses regarding ethnic identity in a group with mixed racial heritage and marginal social status. First, it was proposed that the construct of ethnic identity would be structurally valid for so-called 
Coloureds. To test this hypothesis, a factor analysis of items from a measure designed to assess only ethnic identity would be performed, with the expectations that extraction of a single factor would support the hypothesis and that extraction of more than one factor would indicate that the so-called Coloured participants responded to the items in a way not intended by the measure's authors. Second, it was proposed that the ethnic identity of so-called Coloureds would be positively associated with prejudicial attitudes toward other groups, an assumption consistent with social identity theory and with theories of ethnocentrism (LeVine \& Campbell, 1972; Tajfel, 1978).

Method

\section{Participants}

A total of 70 so-called Coloured adults attending two universities in South Africa were recruited in 1999 from introductory social science classes. All participants completed previously published measures of ethnic identity, anti-White attitudes, and racist attitudes in their classrooms. The majority (53\%) of participants were first-year students, with the average age of the sample being 21.7 years. Of the participants, 55\% were female, and 59\% reported coming from middle-class socio-economic backgrounds. $\underline{\text { Measures }}$

To assess ethnic identity, the Multigroup Ethnic Identity Measure (Phinney, 1992) was administered. Items are positively worded and are rated on a 4-point Likert-type scale with higher values reflecting stronger ethnic identity. This measure has been used in multiple studies across many ethnic groups with acceptable psychometric characteristics (Roberts, Phinney, Masse, Chen, Richard, Roberts, \& Romero, 1999; Worrell, 2000), with reliability estimates across twelve studies ranging from .76 to .92 and the majority 
being in the upper .80s. A factor analysis of the 20-item version of the Multigroup Ethnic Identity Measure resulted in two factors: one for the 14 items measuring Ethnic Identity and another for the 6 items measuring Other Group Orientation (Worrell, 2000). Another factors analysis yielded similar results (Roberts et al., 1999), except that the two negatively worded items assessing Ethnic Identity loaded on a third factor. The authors of the Multigroup Ethnic Identity Measure subsequently removed those two items from the measure itself. Thus the refined 12-item version of the Multigroup Ethnic Identity Measure was administered in this study.

The Anti-White Scale (Duckitt \& Farre, 1994) was used to assess prejudice against White participation in the social, economic, and political contexts of South Africa and the perceived necessity for Whites to suffer retribution for the wrongs of Apartheid. The Subtle Racism Scale (Duckitt, 1991, 1993) was used to evaluate acceptance of interracial contact and the aspiration for equal status among all races. Whereas overt beliefs regarding racial inferiority characterize traditional racism, the construct of subtle racism describes implicit racial biases that are more socially acceptable and more common in contemporary society than traditional racism (Duckitt, 1991). Both the Subtle Racism Scale and the Anti-White Scale consist of 10 items answered on a 7-point Likert-type scale, and both were developed in South Africa specifically for use with South African populations. High scores on the Subtle Racism Scale are indicative of racial prejudice, while high scores on the Anti-White Scale indicate tolerant attitudes toward Whites. Authors have reported acceptable reliability coefficients (ranging from .76 to .91) and acceptable content and construct validity estimates in studies using the scales (Duckitt, 1991, 1993; Duckitt \& Farre, 1994). 


\section{Results}

Mean scores, standard deviations, and ranges on the dependent measures were as follows: $\underline{\mathrm{M}}=33.6$ ( $\underline{\mathrm{SD}}=6.4$; range 12 to 48 ) for the Multigroup Ethnic Identity Measure; $\underline{\mathrm{M}}=29.3$ ( $\underline{\mathrm{SD}}=7.6$; range 10 to 47$)$ for the Subtle Racism Scale; and $\underline{\mathrm{M}}=52.9$ ( $\underline{\mathrm{SD}}=6.7$; range 40 to 68) for the Anti-White Scale. Interpreting these scores by dividing the group mean by the number of items on the measure and then comparing that result to the Likerttype scale used, it appears that this sample endorsed moderate levels of ethnic identity (average score of 2.8 on a 4-point Likert-type scale, with scores above the mid-point of 2.5 indicating endorsement of ethnic identity), moderately low levels of racist sentiment (average score of 2.9 on a 7-point Likert-type scale, with scores below the mid-point of 4.0 indicating racial tolerance), and moderately low levels of anti-White sentiment (average score of 5.3 on a 7-point Likert-type scale, with scores above the mid-point of 4.0 indicating disagreement with anti-White sentiments). These mean scores are similar to those found in previous investigations (Smith \& Stones, 1999; Duckitt, 1993; Duckitt \& Farre, 1994).

A principal components factor analysis was conducted to investigate the structure of the Multigroup Ethnic Identity Measure in the current sample. Based on the resulting scree plot, a single factor was extracted from the data that accounted for $41.4 \%$ of the variance in the 12 items. All items loaded on this factor above .35, and all but one loaded above .50. An additional analysis yielded an internal consistency coefficient (Cronbach’s alpha) of .87. Thus the Multigroup Ethnic Identity Measure appears to reliably assess a uni-dimensional construct of ethnic identity in this sample. 
To assess the relationships among ethnic identity, subtle racism, and anti-White sentiment, Pearson correlations were computed. The Anti-White Scale was mildly negatively correlated $(\underline{\mathrm{r}}=-.25, \underline{\mathrm{p}}<.01)$ with the Subtle Racism Scale, indicating that antiWhite sentiments were negatively associated with racial tolerance. The Multigroup Ethnic Identity Measure and the Subtle Racism Scale were not significantly associated $(\underline{r}=-.14$, $\mathrm{p}>$.05). Interestingly, the Multigroup Ethnic Identity Measure was correlated .27 ( $\mathrm{p}<$ .01) with the Anti-White Scale, indicating that stronger ethnic identity was associated with tolerance toward Whites in this sample. However, the magnitude of the statistically significant correlations was in the moderate range (Cohen, 1987), indicating that the relationships only accounted for a modest amount of the variance.

\section{Discussion}

The first hypothesis of this study, that the construct of ethnic identity would be structurally valid in a group of mixed racial origin was supported by the data. The MEIM items were internally consistent, and they measured the construct of ethnic identity in a unitary way, as intended by the author of the scale. These data are similar to those reported across other ethnic groups (Roberts et al., 1999), and they support the prediction of social identity theory that in-group identity is similarly salient across all identifiable groups, regardless of the type of group.

The hypothesis that the more strongly individuals identify with their own group, the more bias they will show against other groups was not supported in this study. In fact, the opposite relationship was found when anti-White attitudes were assessed: stronger ethnic identity among the so-called Coloured participants was significantly but mildly related to tolerance of Whites. This association may be explained by the marginal social 
status of so-called Coloureds in South African society (e.g., Kinloch, 1985; Moller \& Schlemmer, 1989) and the tendency for low status groups to show favoritism toward high status groups when social status is perceived as being stable over time (Levin, Federico, Sedanuis, \& Rabinowitz, 2002; Sidanius \& Pratto, 1999). Support for this interpretation comes from the finding that although the measures of subtle racism and anti-White sentiment were significantly related (denoting the common construct of out-group prejudice/tolerance), ethnic identity was related only with attitudes toward a high status out-group (Whites) and not toward out-groups in general. Although the correlations obtained were of small to moderate magnitude, these results are consistent with the postulate of social dominance theory that in-group identity and out-group prejudice are mediated by social status (Sidanius \& Pratto, 1999).

Limitations of the present research include the correlational design employed and the restricted range of educational status, age, and socio-economic background of the sample. Furthermore, the limited sample size may have adversely impacted the stability of the factor analytic results. Conducting a factor analysis with a small number of participants greatly restricts the confidence that can be placed in the findings, although MacCallum, Widaman, Zhang, and Hong (1999) describe justifications for the use of factor analysis with small samples. Future research should attempt to replicate the findings on a larger sample of adults from community settings. Furthermore, because socalled Coloureds are a distinct ethnic group, these findings should not generalize to individuals of mixed racial background not associated with a prevalent social group (e.g., multiracial individuals in North America). Future work should be conducted to verify if a uni-dimensional construct of ethnic identity is valid in other contexts. 


\section{References}

Aikins, A. L. (1995) Biracial identity development and alienation in racially mixed adults. Dissertation Abstracts International: Section B: The Sciences and Engineering, 56(5-B), 2851.

Bornman, E., \& Appelgryn, A. E. M. (1999) Predictors of ethnic identification in a transitionary South Africa. South African Journal of Psychology, 29, 62-71.

Cohen, J. (1987) Statistical power analysis for the behavioral sciences. Hillsdale, NJ: Erlbaum.

Duckitt, J. H. (1991) The development and validation of a subtle racism scale in South Africa. South African Journal of Psychology, 21, 233-239.

Duckitt, J. H. (1993) Further validation of a subtle racism scale in South Africa. $\underline{\text { South }}$ African Journal of Psychology, 23, 116-119.

Duckitt, J. H., \& Farre, B. (1994) Right-wing authoritarianism and political intolerance among Whites in the future majority-rule South Africa. The Journal of Social Psychology, 134, 735-741.

Kinloch, G. C. (1985) Racial attitudes in South Africa: a review. Genetic, Social and General Psychology Monographs, 111, 261-281.

Levin, S., Federico, C. M., Sidanius, J., \& Rabinowitz, J. L. (2002). Social dominance orientation and intergroup bias: The legitimation of favoritism for high-status groups. Personality and Social Psychology Bulletin, 28, 144-157.

LeVine, R. A., \& Campbell, D.T. (1972) Ethnocentrism: Theories of conflict, attitudes and group behavior. New York: Wiley. 
MacCallum, R. C., Widaman, K. F., Zhang, S., \& Hong, S. (1999) Sample size in factor analysis. Psychological Methods, 4, 84-99.

Middlebrook, D. L. (1996) Self-stigmatization in racially-mixed people: the social psychological consequences of being “squeezed” between cultures. Dissertation Abstracts International: Section B: The Sciences and Engineering, 57(1-B), 0764. Moller, V., \& Schlemmer, L. (1989) South African quality of life: A research note. Social Indicators Research, 21, 279-291.

Phinney, J. S. (1992) The multigroup ethnic identity mesaure: A new scale for use with diverse groups. Journal of Adolescent Research, 7, 156-176.

Roberts, R. E., Phinney, J. S., Masse, L. C., Chen, Y. R., Roberts, C. R., \& Romero, A. (1999) The structure of ethnic identity of young adolescents from diverse ethnocultural groups. Journal of Early Adolescence, 19, 301-322.

Root, M. P. P. (Ed.) (1992) Racially mixed people in America. Newbury Park, CA: Sage.

Sidanius, J., \& Pratto, F. (1999) Social dominance: An intergroup theory of social hierarchy and oppression. New York: Cambridge Univer. Press.

Smith, T. B., \& Stones, C. R. (1999) Identities and racial attitudes of South African and American adolescents: A cross-cultural examination. South African Journal of Psychology, 29, 23-29.

Tajfel, H. (1978) The psychological structure of intergroup relations. In H. Tajfel (Ed.), Differentiation between social groups. London: Academic Press. Pp. 27-100.

Tizard, B., \& Phoenix, A. (1995) The identity of mixed parentage adolescents. Journal of Child Psychology and Psychiatry and Allied Disciplines, 36, 1399-1410. 
Worrell, F. C. (2000) A validity study of scores on the Multigroup Ethnic Identity

Measure based on a sample of academically talented adolescents. Educational and Psychological Measurement, 60, 439-447. 


\section{Footnote}

${ }^{1}$ Dissatisfaction with the term “Coloured," which was coined by colonial powers, has led to the recent practice of referring to this group as the "so-called Coloureds." 